\title{
Domesticating Elk in a Russian National Park
}

\section{By Yuri Yazan and Yevgeny Knorre}

In the Pechero-Ilych National Park, at the foot of the Ural Mountains in northern European Russia, where a 3-foot snow cover may lie for seven months of the year, experiments in the domestication of elk have been going on for some years. In this article the Director of the Park and his senior research worker describe the wildlife of this large Park, covering 2,758 square miles, and the history of the domesticated elk herd, and estimate the herd's value in the economy of the taiga. The Park gets its name from two rivers which form the western and southern boundaries. A third river, the Kozhim forms the northern boundary, and the Urals the eastern.

THE Pechero-Ilych National Park was created to preserve the Siberian sable, a highly valuable little animal which is not found anywhere else in Europe. Today our work has expanded. As well as protection, our tasks are now to study and increase the numbers and variety of the game animals and birds in the Pechora taiga, which include Siberian sable, pine marten, a hybrid of the two, elk, reindeer, beaver and grouse; to study (and improve) the salmon spawning conditions in the upper reaches of the Pechora and the Ilych rivers; to do experimental work on the biology of the elk ; and to make vegetation studies especially on the cedar, pine and spruce, and the soils.

The park includes two distinct types of landscape : the Pechora River lowlands covered with pine forest, and the Northern Ural Mountains, their foothills covered with spruce, fir and mixed spruce-fir forests, with a good mingling of cedar. The climate is continental, with a mean annual fluctuation in air temperature of $36^{\circ} \mathrm{C}$. During the vegetative stage, which lasts about five months, the average temperature is $2^{\circ}$ to $3^{\circ} \mathrm{C}$ higher in the southern parts of the park than in its northern parts, and $8^{\circ}$ to $9^{\circ} \mathrm{C}$ higher in its flat western area than in its hilly and mountainous eastern area. A change in air temperature of only $1^{\circ} \mathrm{C}$ corresponds to a four-day difference in the phenological dates of spring development of the vegetation. Mean annual air temperature varies from year to year, fluctuating between $-0.8^{\circ}$ and $-2 \cdot 5^{\circ} \mathrm{C}$, and the rivers are frozen from late October or early November until late April or early May. Precipitation totals about 500 to $550 \mathrm{~mm}$. a year and is greatest in the summer. In winter a snow blanket that reaches a depth of 100 to $130 \mathrm{~cm}$. covers the ground for some seven months.

Both Asiatic and European species are represented among the 200 kinds of birds and forty kinds of mammals that inhabit the park. Elk number some 3,000 . They reproduce comparatively rapidly, one cow giving birth to one or two calves annually. Because of their large numbers and the 
uneven distribution of winter pasture their annual seasonal migrations may take them up to $300 \mathrm{~km}$. (187 miles) in one direction. The reindeer are found in the northern part of the reserve.

The Park is the only place in the world where the Siberian sable, the pine marten, and the hybrid of the two inhabit the same forests. They resemble one another closely both in appearance and behaviour, and all three feed mainly on rodents of the mouse family, grouse, pine seeds and, more rarely, squirrels and small birds. Not so long ago it was observed that the squirrel population in the Soviet Union had begun to decrease, and the blame was put on the growing numbers of martens and Siberian sables. However, we established that one marten accounts for only seven to ten squirrels in a year, and a sable even fewer than that, in both cases numbers much too small seriously to affect the squirrel population. In fact the squirrels depend on the crop of conifer seed, and this was confirmed in the 1962-63 hunting season, when a good crop of conifer seed was followed by a sharp increase in the squirrel population.

Beaver were successfully introduced into the reserve in 1938-40. Previously they had inhabited the basin of the Upper Pechora River, but had been wiped out by intensive hunting. Today they are again well established and have spread widely in the territory. Some are now being trapped and introduced into other parts of the park. Otter, mink, ermine, weasel, fox, white hare, chipmunk and flying squirrel are common, and the polar fox, kolinsky and badger are also to be found. Among the birds are capercaillie, black grouse, hazel grouse, willow and rock ptarmigan, and quail. As well as salmon, which come to spawn, the rivers hold Pechora graylings, some up to two kilograms in weight, whitefish, ide, turbot, perch and pike. In the Ilych, there are also brown trout.

\section{Increase in Animals and Birds}

The setting up of the National Park increased the population of game animals and birds, not only in the park itself but also in the adjacent forests. Elk increased more than tenfold ; reindeer, fourfold ; otter, fivefold, and marten over fifteenfold. Now every year marten, elk, and several other mammals leave the park for the adjacent forests. Local hunters always try to hunt as close to the boundaries of the park as possible.

In 1949 it was decided to establish an experimental elk farm in the Park with the idea of raising a domestic animal just as specialised for the taiga zone as the reindeer is for the tundra, the yak for high mountain areas or the camel for the desert. The experiment started with a herd of fourteen tame animals all under three years old, and today there are domesticated animals of the third and fourth generation in the herd, all direct descendants of the first fourteen.

New-born calves up to five days old were found to be the most suitable for bottle-feeding on cows' milk and for domestication. They do not show any fear of man and, having lost their mother, follow him around of their own accord. They readily drink cow's milk from a feeding bottle and become attached for life to the individual feeding them. Such calves can be turned loose without fear that they will run away. At the age of three the tame animals usually bear their first calves and in subsequent years reproduce 
regularly. Some nearly always have two calves; others usually one calf; while with others the chances of producing one or two calves are about even. The farm has thus disproved the widely held belief that elk would not reproduce in captivity and shown the practicability of rearing domesticated elk. Moreover some of the animals are now twelve years old and only one adult has died of disease. The best results seem to come from a system of year-round unrestricted grazing in the taiga, with the animals, unattended by a herdsman, periodically rounded up for check-ups at the farm, and held in temporary corrals during the calving and mating season. Construction of large "stationary" corrals, involving considerable expense, would make elk breeding hardly a paying proposition.

\section{A Good Meat Animal}

The management of domesticated elk is a matter of great importance in the taiga of the north and three possible ways of using them have been studied : as sources of meat, of milk, and as draught animals.

As a source of meat the domesticated elk is highly productive. First, the inevitable loss of meat due to wounded animals getting away when hunted in the wild is avoided. Second, domestication permits the meat productivity of the elk to be managed by selection and feeding. Third, castration of bulls excludes the appreciable losses in their meat output caused by the abrupt drop in their fatness and weight during the mating season (September-October). Sexually mature domesticated bulls which have fattened up over the summer to a live weight of 400-500 kg. drop to $320-360 \mathrm{~kg}$. during the mating period, losing up to 20 per cent of their meat output, primarily at the expense of their fat accumulations; castrated domestic bulls on the other hand, remain in their well-fed state until the beginning of winter, when the slaughter of meat animals begins. In natural conditions, when the most nutritious green fodder is exhausted the calves stop growing for the whole winter. Consequently, six-monthsold and year-old calves usually have the same live weight. But when the domesticated calves on the farm were given additional forage in the form of potatoes and fodder root crops, they continued to gain in weight throughout the whole winter, by as much as $40-80 \mathrm{~kg}$. This enabled the farm to obtain year-old calves with the record live weight of $208 \mathrm{~kg}$.

\section{Cows That Know Their Milking Time}

Experimental work is now under way to study the possibilities of using elk as dairy animals as well. It has been established that the milking process does not present any difficulties or danger to the milkers. When calves were taken away from their mothers immediately after birth and bottle-fed, the milk cows were found to transfer their maternal instinct to the milkers. The cows even returned punctually from their pastures to the farm for milking, which simplified the milking operation considerably.

At first a milk yield of 75 to 150 litres per cow was obtained for the lactation period. Today the top figure has been boosted to 430 litres per experimental cow by various milking methods, the average daily yield having been raised from 2 to 6 litres. These initial successes in increasing the milk yield of elk cows is especially important in view of the fact that, 
with the poor pasture and indifferent hay in the Upper Pechora area, the yield of local milch cattle is low. Elk milk contains, on the average, 10 per cent of fat, some 15 per cent of protein, and many vitamins. Appreciable differences in milk yield between cows suggests possibilities of boosting milk productivity by selective breeding and opens up new, as yet untapped, possibilities for milk production in the taiga.

Experiments with elk as draught animals have proved that with proper training that takes into account the biological peculiarities of the animal, they can be successfully used in the roadless conditions of the taiga to draw sleds, and carry a rider or packs. The maximum useful load the elk can haul or carry is $500 \mathrm{~kg}$. in a sled and $120 \mathrm{~kg}$. in the saddle. On an even, well-trodden, snow-covered road, an elk was found to come to a halt when the load it was hauling reached $1,861 \mathrm{~kg}$. As expected, the castrated elk proved to possess the greatest capacity for work, and under a proper system, work has a favourable effect on the general physical condition of the elk. The draught elk, that is the castrated animals, have the biggest live weight, best developed muscles and maximum fatness of all those on the farm.

Only fourteen years separate the domesticated elk at the experimental farm from their wild ancestors, but they already measure up to all the demands made of domesticated animals : they normally and regularly reproduce in domestic conditions; turned loose in the taiga they do not turn wild but return to the farm; they are used both as productive and draught animals. Certainly the elk's adaptability was underrated in the past. Today a carefully worked out training and management has given it a useful place in the national economy.

\section{NEWS ITEMS}

An Australian Conservation Foundation has been set up to conserve the fauna and flora of the continent. It is the first national body specifically concerned with wildlife conservation. An unofficial organisation, it will preserve important areas, stimulate public interest and aid educational projects. The President is Sir Garfield Barwick, Chief Justice of the High Court of Australia.

It is believed that there are only sixty to eighty brown bears left in the whole of the Pyrenees. French conservationists are calling for a national park to protect them, and also the lammergeier, the capercaillie and the chamois whose numbers are low. The ibex is already extinct in the French Pyrenees.

The wildlife of British Guiana is "depleted to a dangerous level ", thanks to wasteful and indiscriminate killing, destruction of habitats, and the use of insecticides and weedicides, says a memorandum presented recently to the Ministry of Home Affairs by the Natural History Society of British Guiana. The poison chemicals, it says, have worked havoc on the population of turkey vultures and hawks. The Society urges the need for new protection legislation and the creation of a permanent Wildlife Commission. 